\title{
(2) OPEN ACCESS \\ Co-producing a social determinants of health questionnaire for an urban population in community child health
}

\author{
Guddi Singh (D) , ${ }^{1,2}$ Aisha Damarell ${ }^{3}$
}

\begin{abstract}
${ }^{1}$ Mary Sheridan Centre for Child Health, Guy's King's College and Saint Thomas' Hospitals' Medical and Dental School of King's College London, London, UK

${ }^{2}$ Faculty of Social Science and Public Policy, King's College London, London, UK

${ }^{3}$ Royal Hospital for Sick Children, Edinburgh, UK
\end{abstract}

\section{Correspondence to} Dr Guddi Singh, Mary Sheridan Centre for Child Health, Guy's King's College and Saint Thomas' Hospitals' Medical and Dental School of King's College London, London SE11 4TH, UK; guddi.singh@nhs.net

Received 26 June 2020 Revised 30 December 2020 Accepted 28 January 2021

\section{A) Check for updates}

(c) Author(s) (or their employer(s)) 2021. Re-use permitted under CC BY-NC. No commercial re-use. See rights and permissions. Published by BMJ.

To cite: Singh G, Damarell A. Arch Dis Child Educ

Pract Ed Epub ahead of print: [please include Day Month Year]. doi:10.1136/ archdischild-2020-319940

\section{SUMMARY}

We used quality improvement (QI) and coproduction methodologies to explore how child health professionals can be helped to open up conversations about poverty and other social issues in a London community child health clinic between July and October 2019.

\section{THE PROBLEM}

Poverty is inextricably linked to poorer health, educational and social outcomes for children. ${ }^{1}$ These influences are evident in each child and family accessing community paediatric services across the country but particularly in urban areas and areas of higher deprivation, such as the Specialist Children's and Young People Services (SCYPS) in Newham where this project was based. There are strong clinical, public health and moral grounds for paediatricians and other child health professionals identifying, preventing or mitigating the impacts of poverty and other social determinants on child health. ${ }^{2}$ However, questions regarding money, housing and food insecurity are not consistently or uniformly addressed in clinic, with clinicians citing awkwardness and embarrassment as common reasons for not doing so, even though parents themselves want to be asked. ${ }^{3}$ This is leading to missed opportunities to help families with pressing social concerns and to improve the quality of population health.

\section{AIM}

Following on from our work looking at poverty screening tools in the acute paediatric setting, ${ }^{4}$ this pilot project focused on the perceived discomfort related to probing social history taking in the community. With the explicit intention of involving both service users and the wider multidisciplinary team (MDT), we aimed to co-create a refined clinical screening tool for social risk factors by October 2019. The project also aimed to explore attitudes and obstacles to discussing sensitive issues related to poverty through implementation of the screening tool in service.

\section{MAKING A CASE FOR CHANGE}

In order to be able to address issues such as sensitivities around asking about social problems, and to circumvent on-the-ground logistical concerns about time and effort, this project consciously sought to involve a wide range of stakeholders from the outset. Over several weeks, we introduced a series of local child poverty teaching sessions. These were jointly conceived and delivered by a MDT composed of a paediatrician (lead author), speech and language therapist, occupational therapist and physiotherapist. Teaching sessions were voluntary but open to the entire workforce including clinical team leads, managers and patient participation representatives. These sessions were driven by and culminated in consensus that a failure to address social determinants was leading to worse outcomes for patients and they evoked a collective desire to tackle this from within the clinic. Importantly, the high levels of participation and enthusiasm arose organically and subsequent sessions were organised to garner the ideas and input of the MDT; the authors did not lead this from the top-down. These collaborative discussions resulted in a collective decision to focus on interventions or tools that could be used within the clinic to identify and address issues relating to poverty. This led to the idea to co-develop the previous 


\section{Social Determinants of Health Questionnaire}

This questionnaire aims to identify areas of everyday living which can be missed during appointments but impact families and their healthcare. It will be given out to all families coming to our clinics. We hope to improve our services by picking up on these issues and worries so we can offer advice and support.

For each statement, please mark on the scale how relevant it is to you and your family i.e. how closely each statement fits with your situation.

1. Lack of access to affordable and reliable transport has made it difficult for me to get to this medical appointment or has caused me to miss medical appointments for my child/ children in the past.

How relevant is this to you with 0 being not relevant at all and 5 being very relevant?

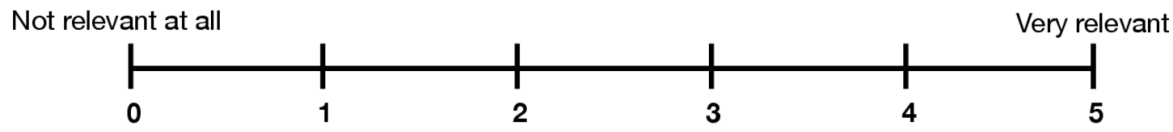

\section{I worry about being able to pay for my housing and/or my electricity/heating bills.}

How relevant is this to you with 0 being not relevant at all and 5 being very relevant?

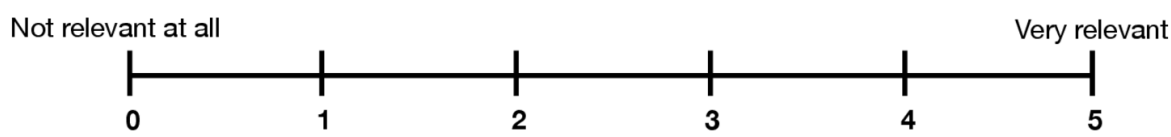

\section{I worry about where my family live due to one or more of the following problems: \\ - Pests e.g. bugs, mice or rats \\ - Mold, damp or leaks \\ - Broken heating/oven \\ - Missing smoke detectors \\ - Difficulty accessing house/flat (e.g. due to a disability, too many stairs, poor lighting) \\ - Not enough space}

How relevant is this to you with 0 being not relevant at all and 5 being very relevant?

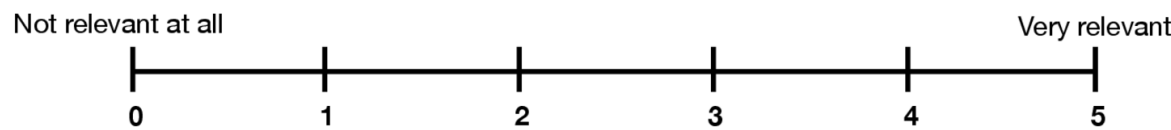

Figure 1 Social Determinants of Health Questionnaire (SDH-Q) for use in clinic.

work of the lead author, with a survey and resource leaflet being two of the ideas raised and discussed by the whole MDT. Thus, the case for change was 'co-created' by the very health professionals and patients this project aimed to help. Given this widespread support, senior clinical leads green-lighted our proposal to develop a social screening tool to help facilitate conversations about the social determinants of health with families.

\section{OUR IMPROVEMENTS}

Screening and referral is widely invoked and well evidenced as a tool for clinicians to contribute to the mitigation of social deprivation and poverty. ${ }^{5}$ As many of these approaches have been developed outside the
UK or for adult populations, we sought to innovate this premise to suitour service.

Our social screening tool (figure 1) and accompanying resource leaflet (figure 2) were devised and refined via a series of Plan-Do-Study-Act (PDSA) cycles (figure 3). The leaflet was created to offer robust and tangible help to families once concerns had been elicited. Potential screening questions as well as different formats and contents for the resource leaflet were drafted, using our previous work ${ }^{4}$ and existing local information. Both artefacts were subsequently tested and refined to be user-friendly, non-stigmatising and relevant to both patients and clinicians.

We involved, and used qualitative feedback from, around 20 service users and 30 staff members 

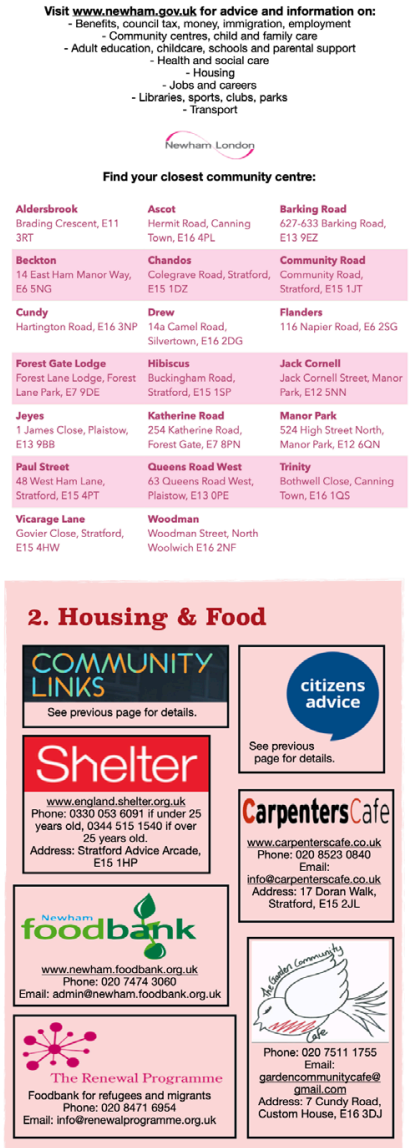
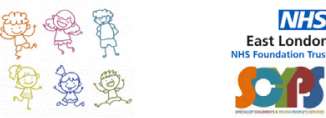

Specialist Children's and Young People's Services

West Ham Lane Centre

Resource Leaflet for Parents \& Carers
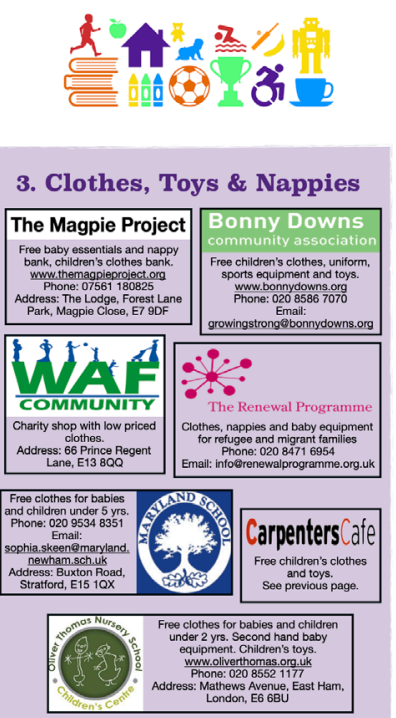

\section{Contents:}

1. Income

2. Housing \& Food

3. Clothes, Toys \& Nappies

4. Clubs \& Activities 5. Safety

6. Courses \& Education

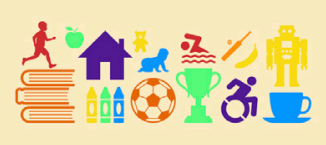

\section{Clubs \& Activities}

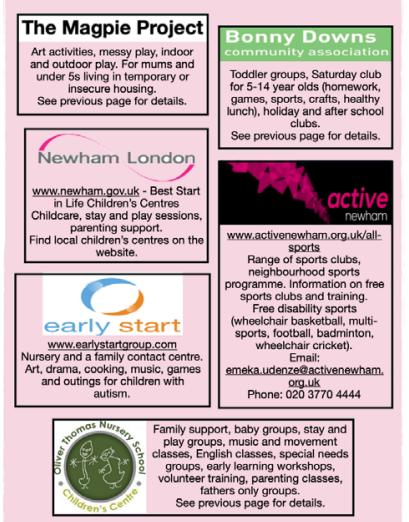

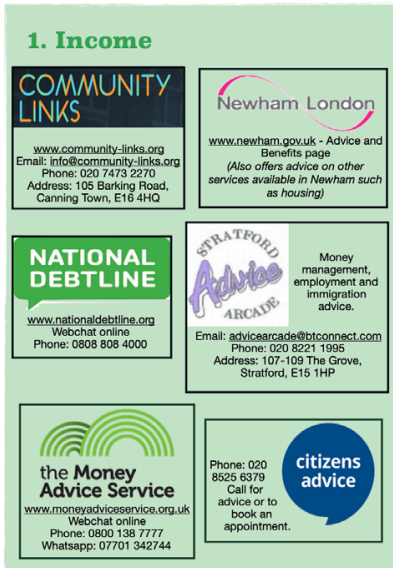

5. Safety

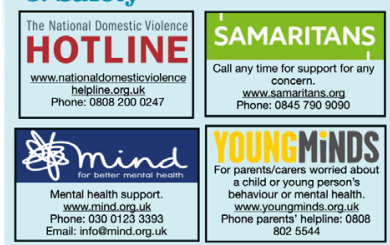

6. Courses \& Education

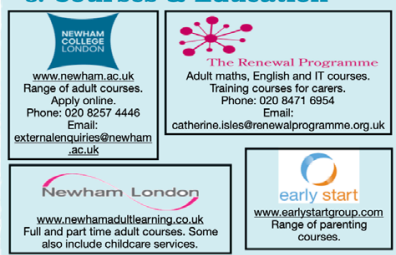

Figure 2 Co-produced resource pack to address social problems in Newham.

\begin{tabular}{|c|c|c|c|c|}
\hline $\begin{array}{l}\text { PDSA } \\
\text { Test } \\
\text { Number }\end{array}$ & Plan & Do & Study & Act \\
\hline 1 & $\begin{array}{l}\text { Create first draft of social } \\
\text { screening tool using previously } \\
\text { tested tools and previous work }\end{array}$ & $\begin{array}{l}\text { Reflection on questions } \\
\text { selected, feedback from other } \\
\text { team members }\end{array}$ & $\begin{array}{l}\text { Tick-box style questionnaire does not } \\
\text { provide enough detail to be useful to } \\
\text { MDT }\end{array}$ & $\begin{array}{l}\text { Re-create tool in order to accumulate } \\
\text { more information to increase usefulness }\end{array}$ \\
\hline 2 & $\begin{array}{l}\text { Open-ended questions }+ \text { free } \\
\text { text used as alternate to tick- } \\
\text { box style tool }\end{array}$ & $\begin{array}{l}\text { Test idea with team members } \\
\text { and service users }\end{array}$ & $\begin{array}{l}\text { High-barrier to participation including } \\
\text { time, literacy and language }\end{array}$ & $\begin{array}{l}\text { Adapt tool to include sliding, Likert-type } \\
\text { scare } \\
\text { - Better visually, transcends language } \\
\text { - More information than tick-box but } \\
\text { quicker and fewer barriers than open } \\
\text { questions } \\
\text { Modify tool by reducing question number } \\
\text { and detail }\end{array}$ \\
\hline 3 & $\begin{array}{l}\text { Tool to acknowledge deprivation } \\
\text { is relative }\end{array}$ & $\begin{array}{l}\text { Ensure phrasing/definitions not } \\
\text { absolute and allow for } \\
\text { identification of ideas for further } \\
\text { discussion in clinic }\end{array}$ & $\begin{array}{l}\text { Feedback on ease of use of } \\
\text { questionnaire by service users } \\
\text { Positive feedback, improvement from } \\
\text { previous draft tools }\end{array}$ & $\begin{array}{l}\text { Tool ready for more widespread use } \\
\text { within service, to be distributed in waiting } \\
\text { areas prior to clinic appointments }\end{array}$ \\
\hline 4 & $\begin{array}{l}\text { Create information leaflet to } \\
\text { allow families to be offered help } \\
\text { as a result of screening tool } \\
\text { findings }\end{array}$ & $\begin{array}{l}\text { Research local resources and } \\
\text { contact information } \\
\text { Using previous work as a guide }\end{array}$ & $\begin{array}{l}\text { Need for easy to hand out } \\
\text { information sheet } \\
\text { Resources need to be grouped into } \\
\text { relevant categories }\end{array}$ & $\begin{array}{l}\text { Create leaflet with categorised pages, } \\
\text { including housing, income and food } \\
\text { Colour coordination for usability } \\
\text { Picture/logo, contact details and address } \\
\text { for each service }\end{array}$ \\
\hline 5 & $\begin{array}{l}\text { Leaflet needs further categories } \\
\text { for areas of concern raised as a } \\
\text { result of screening tool feedback }\end{array}$ & $\begin{array}{l}\text { Local resources found for } \\
\text { - Charities offering free } \\
\text { clothes, toys and nappies } \\
\text { - Adult learning courses } \\
\text { - Free clubs, activities and } \\
\text { baby/toddler groups } \\
\text { - Safety helplines }\end{array}$ & $\begin{array}{l}\text { Positive feedback on range of } \\
\text { categories included, desire for local } \\
\text { community centre addresses to be } \\
\text { added to leaflet }\end{array}$ & $\begin{array}{l}\text { PDF and printed copies of leaflet created } \\
\text { with addition of community centre } \\
\text { addresses } \\
\text { Leaflet able to be handed out at clinics or } \\
\text { emailed to families }\end{array}$ \\
\hline
\end{tabular}

Figure 3 PDSA cycles demonstrating refinement of social screening tool. 
Table 1 Exemplar qualitative feedback regarding feelings about discussing social problems in clinic from both service users and clinicians

How do you feel about discussing social problems in clinic?

\begin{tabular}{ll}
\hline (A) Service users & (B) Multidisciplinary team \\
\hline "I think lots of people suffer in silence. & "I know it is important but we are pushed \\
People can't do what the therapist & for time already. Our appointments are \\
suggests if they don't have space or & shorter than they used to be and we need \\
money for equipment. It needs to be & to fit the same amount into them. We just \\
addressed first, the stuff the therapist & don't have time to ask all these questions... \\
suggests can't be done sometimes & a questionnaire would help this I suppose \\
without the other stuff being addressed & and then it would be easier to tell who \\
first" & needs help" \\
"It is the main issue. For us it is difficult & "I would feel uncomfortable asking if I \\
just getting here" & didn't know how I could help them" \\
"It is very important for them (doctors & "It's not always easy to tell who needs \\
and therapists) to know even if it is & help. They might be dressed really well and \\
just so they can put it in their notes so & I don't know that they are unable to afford \\
people know we need extra help" & toys" \\
"We've been in emergency housing & "I try to ask these questions in clinic anyway \\
before and there's no time to think & but having a way of identifying the most \\
about it (therapy), then we come here & important issue for each family would make \\
and they don't know about all of that" & it easier" \\
\hline "Doctors already struggle with having & \\
enough time" & \\
\hline "It is important to ask about. They & \\
don't affect me now but they might & \\
be in the future. I would want to know & \\
where to get help in the future" & \\
\hline
\end{tabular}

throughout the co-production process (tables 1 and 2). Notable findings included high levels of service user eagerness to talk about their social circumstances: all service users asked were willing to complete the screening tool, and remarkably, we encountered no negative feedback. This juxtaposed with the relative lack of confidence expressed by clinicians in exploring
Table 2 Feedback from service users about Social Determinants of Health Questionnaire (SDH-Q)

\begin{tabular}{|c|c|}
\hline $\begin{array}{l}\text { "I know they can't always do something } \\
\text { but I think they should ask and know and } \\
\text { it should be on the notes" }\end{array}$ & $\begin{array}{l}\text { "These questions aren't relevant to me } \\
\text { at the moment but they have been in the } \\
\text { past. It is important to be able to offer } \\
\text { support to families in difficulty" }\end{array}$ \\
\hline $\begin{array}{l}\text { "Just nice to know someone cares and is } \\
\text { thinking about these things" }\end{array}$ & $\begin{array}{l}\text { "I would need help [from an interpreter] } \\
\text { to do it" }\end{array}$ \\
\hline $\begin{array}{l}\text { "No point asking without offering any } \\
\text { help" }\end{array}$ & $\begin{array}{l}\text { "I'd be happy to fill it out before we came. } \\
\text { Would be nice if the doctor could tell us } \\
\text { places that could help" }\end{array}$ \\
\hline
\end{tabular}

these issues, with lack of awareness of local resources cited as a major hurdle. It was thus striking to see how effectively the introduction of a local resource pack seemed to 'unlock' the ability and readiness of clinicians to address social issues. Capturing this data has been crucial to learning from the pilot and planning next steps. Table 3 illustrates a case study from our project to help clinicians to see directly how this tool might play out with their patients in practice.

\section{Learning and next steps}

Addressing the health and social burden of poverty and deprivation in health systems requires the development of novel tools and approaches. Our co-produced pilot introducing a clinical social screening tool and resource pack for use in a community child health clinic is instructive both in terms of further refinement and for adaptation for other clinical settings.

First, by allowing us to deal with both service user and provider populations' needs simultaneously, co-production enabled us to leverage PDSA cycles to

Table 3 SDH-Q in action. Case study—Sam*

\footnotetext{
The Presentation

Sam, aged 6 years with attention deficit hyperactivity disorder (ADHD), was referred to clinic for an autism spectrum disorder (ASD) assessment

Using the SDH-Q

Sam's mother, Suzie, was happy to fill out the SDH-Q (see figure 1), on the basis of which her clinician was able to explore the following issues:

Areas of concern on SDH-Q

"Worries about not enough space at home

"Lack of access to transport"

"Worries about paying for housing and/or bills"

"Providing enough food for the family"

"Unable to always afford everyday items for her children"

When asked how she felt about filling in the survey, Suzie said she felt relieved: "It's nice that someone cares about these issues-I've never been asked about my living situation before! But when you think about it, it's actually really important for my doctor to know why I struggle so much". She felt that most advice she'd been given on managing Sam's behaviour was simply impossible given her current situation. "I often feel like a bad mother for not being able to do what's best for Sam". Suzie said she would feel comfortable discussing her home situation with other healthcare professionals but that "It's not easy to bring it up if I'm not asked about it"

After the discussion, Suzie was given a copy of our leaflet with relevant local services highlighted. She was grateful that someone had taken the time to address her concerns and felt that the leaflet would help, as she had not heard of all of the services available

\section{A few months later}

At follow-up, Suzie told Sam's clinician that the leaflet had prompted her to seek help. Advice from the Citizen's Advice Bureau was already helping her to save money on housing and amenities, and visiting a clothes and toy bank meant that she could "now replace clothes that Sam is growing out of, and give him toys and books right for his age. It's taken off a lot of pressure". Suzie had also been receiving significant support from a local community centre, which gives access to clubs and sports for her sons. Suzie now finds she has "more time and headspace to spend with Sam" and follow healthcare professionals' advice. Although not all of her social concerns have been relieved, Suzie was a lot more optimistic about the future, and felt more empowered to engage in Sam's healthcare

*'Sam' is a pseudonym —all names and identifying details have been changed to protect the privacy of individuals.
} 
bring about the most impactful improvements to our tools. Moreover, the collaborative and egalitarian nature of using qualitative feedback to develop our tools resulted in high levels of buy-in and has also helped to distribute responsibility for sustaining the project in the longer term.

Second, the iterative and exploratory process of developing both the screening tool and the resource pack helped to bring to light, and question, assumptions about how healthcare is conventionally delivered. For instance, without careful attention, the reductive nature of healthcare questionnaires can serve to close off arenas of enquiry in the clinician-service user relationship or render responses meaningless by failing to capture what really matters to those involved. How can we guard against the mechanical or computational tendency of such tools and preserve the sanctity of the clinician-service user relationship?

Third, there were many unexpected benefits of the screening tool. For example, it became clear that parents welcomed being asked about social problems sensitively, and such enquiry was felt to occur all too rarely. One parent was moved to tears that she was asked and felt 'cared for' by the health system for the first time. Another parent, initially defensive and guarded in a child protection medical, opened up while using the questionnaire. He explained he did not normally feel he could admit how difficult life at home was because he was afraid his "children would be taken away". For clinicians, the tools

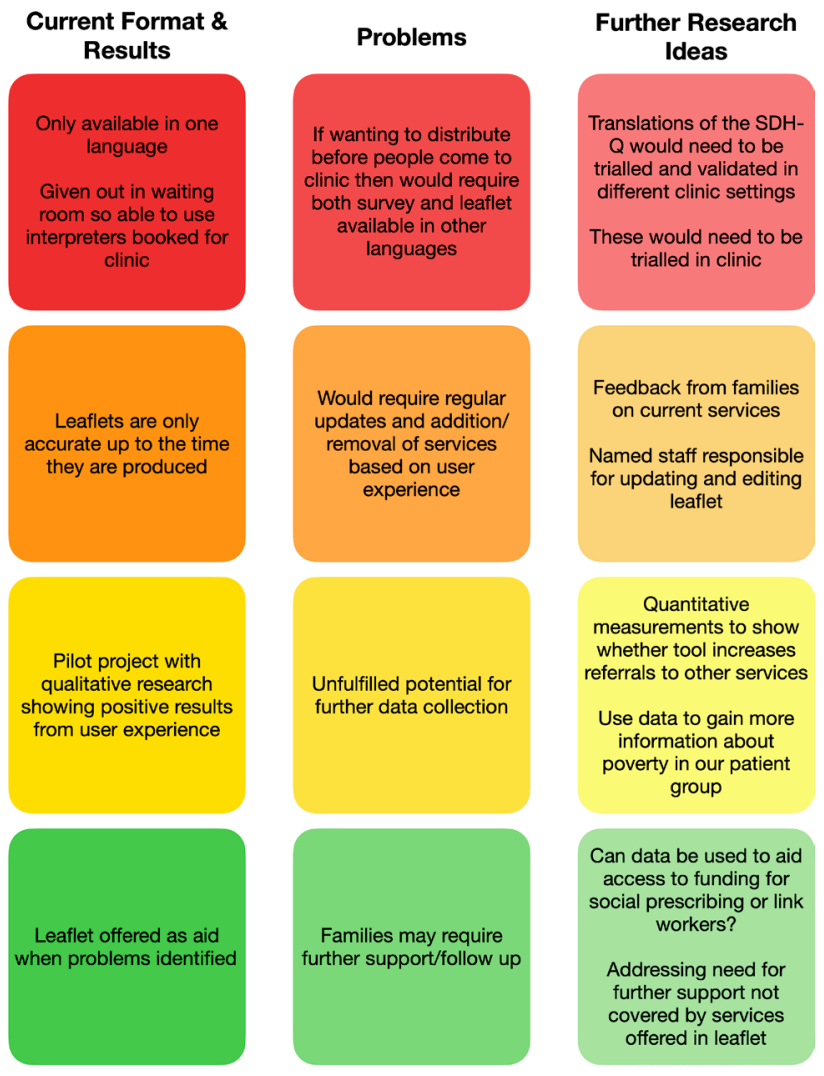

Figure 4 Diagram identifying areas for development. helped to demonstrate that their questioning was not punitive but rather humane in motivation. Moreover, clinicians felt able to 'connect' with their patients in ways that would not normally be possible. Finally, far from taking up extra time, the tool helped clinicians to home in on the issues most pressing for each family, thus enabling them to provide a more patient-centred or 'bespoke' approach to their particular problems.

This pilot explored if QI could be used to contend with the discomfort and resistance to asking about social problems in clinical encounters. While initial results are promising, we are aware that as a pilot study, our sample size was small; one could reasonably foresee more varied responses-including resistance or negative feedbackwith larger sample sizes or in different healthcare settings. Moreover, the implications remain to be established. Could our screening tool prove helpful when used on a larger scale and more regularly? How would we meaningfully validate it? At the moment, our tool is seen as a 'conversation opener'; however, it could conceivably be used for data collection. How can this be done without compromising trust between clinician and service user and to what use would that data be put? Can our tool work in other languages? The development of this pilot has been put on hold during the COVID-19 global pandemic, but the plan is to explore the project further with ongoing co-production locally. figure 4 lays out the potential areas for development and next steps.

The most profound and lasting lesson for the authors was the mismatch between what clinicians aspired to do for their patients and what was possible in reality. Despite deep concern about the impact of social problems on health, clinicians routinely feel hamstrung by institutional priorities and processes that pull in competing directions. This is not particular to SCYPS but rather a feature across the UK healthcare landscape. ${ }^{6}$ To the extent that QI can be used to help health professionals of all stripes to more closely achieve their aspirations for helping patients in challenging times, we hope our lessons prove useful to others.

\section{Twitter Guddi Singh @DrGuddisingh}

Acknowledgements With special thanks to the multidisciplinary team and service users at SCYPS whose input made this QI project possible; the senior management at SCYPS, particularly Dr Joanne Beckmann, for enabling this project to take place; and, last but not least, all the hardworking staff at SCYPS for their tireless and devoted service to the children and families of Newham.

Contributors GS conceived of the project and supervised AD, who was a medical student at the time, to design the QI project, collect and analyse data. GS wrote a first draft and subsequently edited further drafts by $A D$, who also designed all figures and tables under guidance from GS.

Funding This QI project received no specific grant from any funding agency in the public, commercial or not-for-profit sectors.

Competing interests None declared.

Patient consent for publication Not required.

Provenance and peer review Not commissioned; externally peer reviewed.

Data availability statement Data are available on reasonable request.

Open access This is an open access article distributed in accordance with the Creative Commons Attribution Non Commercial (CC BY-NC 4.0) license, 
which permits others to distribute, remix, adapt, build upon this work noncommercially, and license their derivative works on different terms, provided the original work is properly cited, appropriate credit is given, any changes made indicated, and the use is non-commercial. See: http://creativecommons.org/ licenses/by-nc/4.0/.

\section{ORCID iD}

Guddi Singh http://orcid.org/0000-0003-3263-393X

\section{REFERENCES}

1 Royal College of Paediatrics and Child Health (RCPCH). The state of child health (SOCH) 2017 report 2017.

2 Garg A, Toy S, Tripodis Y, et al. Addressing social determinants of health at well child care visits: a cluster RCT. Pediatrics 2015;135:e296-304.
3 Szilagyi M, Kerker BD, Storfer-Isser A, et al. Factors associated with whether pediatricians Inquire about parents' adverse childhood experiences. Acad Pediatr 2016;16:668-75.

4 Singh G, Zhu H. Poverty in practice: using quality improvement in paediatrics to improve identification and support of families living in poverty. Arch Dis Child Educ Pract Ed 2020. doi:10.1136/archdischild-2019-318259. [Epub ahead of print: 27 Jul 2020].

5 Andermann A, CLEAR Collaboration. Taking action on the social determinants of health in clinical practice: a framework for health professionals. CMAJ 2016;188:E474-83.

6 Owens J, Singh G, Cribb A. Austerity and professionalism: being a good healthcare professional in bad conditions. Health Care Anal 2019;27:157-70. 